\title{
Cezaevlerinde Görev Yapan İnfaz ve Koruma Memurlarının İş Doyumu ve Tükenmişlik Düzeyleri Arasındaki İlişkinin İncelenmesi
}

DOI: $10.26466 /$ opus.340269

\section{Muhammet Kayra* - Ahmet Alpay Dikmen**}

\author{
*Öğretmen, Sincan 2 Nolu F Tipi Ceza İnfaz Kurumu Müdürlüğü, Ankara/Türkiye \\ E-posta: muhammetkayra@hotmail.com ORCID: 0000-0001-7322-6682 \\ **Prof. Dr., Ankara Üniversitesi Siyasal Bilimler Fakültesi, Ankara/Türkiye
}

Öz

E-posta: dikmenaa@gmail.com ORCID: 0000-0002-8724-3923

Bu araştırma cezaevlerinde görev yapan infaz ve koruma memurlarının iş doyumu ile tükenmişlik düzeylerinin tespiti ve aralarındaki ilişkinin ölçülmesi amacıyla yapılmıştır. Çalışmada; yaş, çalıma şekli, mesleki kıdem, çalışılan kurumun güvenlik seviyesi gibi mesleki ve demografik değişkenlerin iş doyumu ve tükenmişlik düzeyine etkisi incelenmiştir. Araştırma kapsamında Ankara ilindeki 10 kurumda görev yapan veya eğitime katılan 503 infaz ve koruma memuruna anket uygulamış, 308 anket değerlendirmeye alınmıştır. Araştırmaya katılan infaz koruma memurlarının demografik özellikleri ve niteliklerini belirleyebilmek amacıyla araştırmacı tarafından hazırlanan Kişisel Bilgi Formu, iş doyum düzeylerini ölçmek için Minnesota İş Doyum Ölçeği (MDÖ) ve tükenmişlik düzeylerinin tespiti için Maslach Tükenmişlik Ölçeği (MTÖ) kullanılmıştır. İfaz ve koruma memurlarına uygulanan form ve ölçekler araştırmacı tarafindan tek tek incelenmiş, geçersiz olanlar dişında kalanlar SPSS 20 programı aracılı̆̆ıyla bilgisayar ortamına aktarılmıştır. Minnesota İş Doyum Ölçeği ve Maslach Tükenmişlik Envanteri için ayrı ayrı aritmetik ortalama, standart sapma ve yüzde hesabı yapılmıştır. Araştırmaya katılan infaz ve koruma memurlarının genel iş doyum düzeyleri ile beraber içsel ve dışsal doyum düzeylerinin düşük olduğu sonucuna ulaşılmıtır. Tükenmişlik düzeyleri ile ilgili yapılan analizlerde; infaz ve koruma memurlarının duygusal tükenmişlik düzeylerinin yüksek, duyarsızlaşma düzeylerinin düşük ve kişisel başarı hislerinin yüksek olduğu tespit edilmiştir. Araştırmada elde edilen bir diğer bulgu; iş doyumu ile tükenmişlğin duygusal tükenme ve duyarsızlaşma alt boyutları arasında negatif, kişisel başarı hissi alt boyutu arasında pozitif bir ilişki olmasıdır. Çalışma bulguları, hem kuramsal ve pratik uygulamalar hem de gelecek araştırmalar bakımından tartışılmıştır.

Anahtar Kelimeler: İ̧̧ doyumu, tükenmişlik, infaz ve koruma memurları 


\title{
Investigation of RelationshipBetween Job Satisfac- tion and Burnout Levels of Guardians in Prisons
}

\author{
DOI: $10.26466 /$ opus.340269
}

\begin{abstract}
The current study aims to identify the job satisfaction and burnout levels of guardians in prison and to examine the relationship between them. In this study, the effects of both professional and demographic variables like age, work position, professional seniority and safety level of the institution on job satisfaction and burnout levels were examined. In the scope of the study, questionnaires were distributed to the 503 guardians who work or attended to the training in 10 different institutions in Ankara and 308 questionnaires were returned. Demographic questions (developed by the researcher), Minnesota Job Satisfaction Questionnaire and Maslach Burnout Inventory were used to measure the demographic properties of the guardians and job satisfaction and burnout levels of the guardians. Guardians completed the measures of Minessota Job Satisfaction and Maslach Burnout Inventory. All the questionnaires were controlled by the researcher before entering data to the SPSS 20. Means and standard deviations were calculated for the scales. Results revealed that the guardians have low levels of both intrinsic and extrinsic job satisfaction and low levels of general job satisfaction. In terms of analyses regarding burnout levels, the results showed that guardians have high levels of emotional exhaustion, low levels of depersonalization and high levels of personal accomplishment. Another finding of the current study is general job satisfaction is negatively related with emotional exhaustion and depersonalization subscales of Burnout Inventory and positively related with personal accomplishment subscale of Burnout Inventory. The implications of the study for theory, practice and future research were discussed.
\end{abstract}

Key Words : Job satisfaction, burnout, guardians 


\section{Giriş}

Yarg1 tarafından suçluların cezaevlerine hapsedilmesi kişileri suç işlemekten caydıran en etkili yöntemlerden biri olarak kabul edilmektedir (Akın, 2010) ve suçla mücadelede görev yapan kurumlar arasında cezaevleri en etkin çalışan kurumlardan biri olarak görülmektedir. Cezaevleri fiziksel yapıları ve psikolojik etkenleri nedeniyle diğer kamu kurum ve kuruluşlarından farklı özelliklere sahiptirler. Cezaevlerinde çalışan infaz ve koruma memurlarının, tutuklu ve hükümlülerin sosyalizasyon ve tahliye sonrası yaşama uyumlarının sağlanması noktasında önemli görevleri bulunmaktadır. Bu çalışmada infaz ve koruma memurlarının farklı değişkenlere göre ölçülmesi hedeflenmektedir.

Birçok alanda yapılan araştırmalar olumsuz çalışma koşullarının çalışanların iş doyumunu etkilediğini ve beraberinde tükenmişlik sendromu belirtilerinin ortaya çıktığını göstermiştir. Bu olumsuzluklar zaman içinde çalışanlarda hem fizyolojik hem de psikolojik rahatsızlıklara neden olmaktadır. Bu durumda çalışanlarda işine karşı isteksizlik, işinden hoşlanmama, kaçma, bıkkınlık gibi duygu ve davranışlar görülmektedir. İş doyumsuzluğu ve tükenmişlik sadece bireyleri değil, örgütleri ve hizmet alanları da etkilemektedir. Örgütler performans düşüklüğü sonucunda maddi kayıplar yaşamakta, müşteriler ise daha düşük nitelikli hizmet almak durumunda kalmaktadırlar.

İş doyumu çalışanların örgüt içindeki rollerine ilişkin gösterdikleri duygusal bir tepkidir. Yapılan işe karşı gösterilen olumlu tepki iş doyumu, olumsuz tepki ise iş doyumsuzluğunun belirtisidir (Chen, 2007). Bireyler iş hayatlarındaki koşulların iyileştirilmesini, ekonomik, kişisel, toplumsal ihtiyaçları ile arzu ve isteklerinin karşılanmasını talep ederler. Çalışanlar söz konusu gereksinimleri örgütçe karşılandığı sürece işlerinden tatmin olmaktadırlar (Keser, 2006). 
Büyük çoğunluğu kapalı alanda görev yapan, güvenlik sebebiyle mesai saatlerinde iletişim araçlarından yoksun kalan, bir biçimde suça bulaşmış ve toplum tarafından dışlanan tutuklu-hükümlülere yönelik faaliyetler yürüten infaz ve koruma memurlarının diğer kamu görevlilerine göre olumsuz çalışma koşullarında iş doyumsuzluğu ve tükenmişlik riski altında oldukları yadsınamaz bir gerçektir.

Araştırma bulguları infaz ve koruma memurluğunun stres düzeyi yüksek bir meslek olduğunu göstermektedir. İnfaz ve koruma memurlarına tutuklu-hükümlüler tarafından yapılan baskı ve tehditler, cezaevlerindeki şiddet olayları, tutuklu-hükümlülerin yasa dışı talepleri, yönetim kademesi ile yaşanan sorunlar ve sürekli kapalı alanda çalışmak, memurların yaşadığı en büyük sıkıntılardır.

Tükenmişlik ise genel olarak çalışanların yaptıkları işin amacından uzaklaşması, duygusal anlamda yorgunluk hissi, hizmet sunulanlara karşı duyarsızlık ve nihayetinde yapılan işten psikolojik anlamda kendini geriye çekmek biçiminde tanımlanmaktadır. Tükenmişlik insanlarla birebir çalışmayı gerektiren, hizmet kalitesini insan faktörünün doğrudan etkilediği alanlarda görülmektedir. Bu sebeple tükenmişlik yaşayan bireylerin çalıştı̆̆ örgütlerde hizmet kalitesi olumsuz biçimde etkilenmektedir (Kaçmaz, 2005).

Tükenmişliğin yarattı̆̆ olumsuz sonuçlar stresin doğurduklarına benzese de aralarında önemli farklılıklar bulunmaktadır. Bireyde sinsice ilerleyen bir rahatsızlıktır. Tükenmişliğin yarattığı etkiler sadece bireyi olumsuz yönde etkilemez, bireyin ailesini, çevresini ve çalıştığ 1 örgütü de büyük ölçüde etkisi altına alır. Araştırma sonuçları tükenmişlik yaşayan bireylerin; yorgunluk, iştahsızlık, uykusuzluk, psikosomatik rahatsızlıklar, aile bireyleriyle çatışma, sigara ve alkol kullanımında artış, işinden soğuma ve evlilik problemleri gibi sorunlarla karşı karşıya kaldığını göstermektedir (Kırılmaz, Çelen ve Sarp, 2003).

Araştırma Ankara'da bulunan 9 cezaevi ile 2015 yılı Şubat ve Mart aylarında hizmet içi eğitim faaliyetleri nedeniyle Adalet Bakanlığı Ceza 
İnfaz Kurumları ve Tutukevleri Personeli Ankara Eğitim Merkezinde bulunan infaz ve koruma memurlarını kapsayan anket çalışmasına dayalı olarak gerçekleştirilmiştir. Bu bölümde sırasıyla araştırmanın konusu, amacı ve önemiyle ilgili bilgiler verilecektir.

\section{Araştırmanın Konusu}

İş doyumu bilim insanları tarafından farklı biçimlerde tanımlanmıştır. Bunun en önemli nedeni bireylerin iş doyumunu pek çok faktörün etkilemesidir. Genel olarak çalışanın iş hayatından duyduğu hoşnutluk olarak nitelendirilen iş doyumu, çalışanların beklentilerini çalışılan ortam ya da işin ne ölçüde karşıladığı ile ilgilidir (Akıncı, 2002).

Vroom (1964) iş doyumunu, çalışanların işlerini, iş çevresini ve iş deneyimlerini değerlendirmeleri sonucunda hoşnut olma durumları olarak tanımlamıştır. Vroom'a göre iş doyumu olumlu duygusal bir tepki durumdur. Locke (1969) iş doyumunu; bireylerin işe verdikleri öneme yönelik olarak işlerinde başarılı olması, benzer şekilde bireylerin işlerinde başarılı olmalarını kolaylaştıran, işten haz almayla ilgili duygusal bir durum olarak açılamıştır.

Çalışanlar tarafından işe yönelik olarak; işin kendisi, yöneticilerin tutumu, terfi olanakları ve ücret gibi pek çok değişken değerlendirilmekte, tüm bu değişkenler çalışanların beklentiler ve değerler sisteminden geçmektedir. Bu değerlendirme sonucunda çalışanların zihninde oluşan olumlu veya olumsuz algıları ise iş doyumu veya doyumsuzluğunu oluşturmaktadır (Çekmecelioğlu, 2006). Karmaşık yapısıyla dikkat çeken iş doyumu sağlanamadığı takdirde iş doyumsuzluğu oluşmaktadır. Örgütlerde şartların bozulduğuna dair en önemli gösterge iş doyumunun yeterli düzeyde olmamasıdır. İş doyumsuzluğu; çalışanların işi yavaşlatması, grevler, işi sabote etme, disiplin problemleri ve benzeri olumsuzlukların ardında yer alan bir faktördür (Davis, 1998). 
Tükenmişlikle ilgili olarak yapılan literatür incelemesinde pek çok tanımlamaya yer verildiği ve genel özellikleri itibariyle stres ile benzerliklerinden dolayı karışıklığa yol açabildiği tespit edilmiştir.

Tükenmişlik bireyin işinde yaşadıklarına karşı ortaya koyduğu tepki ve bu tepkinin beraberinde olumsuz tutum ve davranışları getirmesidir. Birey böyle durumlarda hizmet alanlara ve iş arkadaşlarına karşı katı davranışlar sergiler, yaratıcılıktan uzaklaşır, değişikliklere direnir. Tükenmişlik yaşayan bireylerin örgüt içerisindeki başarısızlıklarının kendilerince mantıklı bir açıklaması vardır (Tümkaya, 2000).

Tükenmişlikle ilgili olarak yapılan tanımlardan en bilinen ve kabul göreni ise Maslach tarafından yapılmıştır. Maslach tükenmişliğin, duygusal tükenme, duyarsızlaşma ve kişisel başarıda düşme hissi olmak üzere üç evresi olduğunu ortaya koymuştur. Maslach tükenmişliğin, insanlarla yüz yüze çalışılan mesleklerde daha yoğun görüldügüüü belirtmektedir. Bu mesleklerde, hizmet alanların duygusal talepleriyle karşı karşıya kalan çalışanlarda bir süre sonra yorgunluk, bitkinlik ve umutsuzluk duyguları belirmekte; çalıştıkları örgüte, müşterilere ve arkadaşlarına yansıtılan olumsuz tavır ve davranışlar, çalışanların tükenmişlik sendromu yaşadı̆̆ını göstermektedir (Sürgevil, 2006).

\section{Yöntem}

\section{Araştırmanın Modeli}

Bu nicel araştırmada, cezaevlerindeki infaz ve koruma memurlarının iş doyumu ve tükenmişlik düzeyleri ölçülüp, aralarındaki ilişki tarama modeliyle tespit edilmiştir. Verilerin toplanması sırasında, katılımcılara herhangi bir yönlendirme yapılmamış ve görüşlerinin alınması sağlanmıştır. 


\section{Evren ve Örneklem}

Araştırmanın evrenini Ankara ilinde bulunan 2 adet F Tipi, 2 adet L Tipi, 1 adet T Tipi, 1 adet Çocuk ve Gençlik Kapalı Cezaevi, 1 adet Çocuk Eğitim Evi, 1 adet Açık Cezaevi ve 1 adet Kadın Cezaevi oluşturmaktadır. Ayrıca infaz koruma memurlarının hizmet öncesi ve hizmet içi eğitimlerine yönelik çalışmalar yürüten ve alan araştırması için alınan izin gereği; 2015 Şubat ve Mart ayları içerisinde cezaevlerinde görev yaparken, Adalet Bakanlığı Ceza İnfaz Kurumları ve Tutukevleri Personeli Ankara Eğitim Merkezinde hizmet içi eğitime alınan infaz ve koruma memurlarına da çalışma kapsamında ulaşılmaya çalışılmıştır.

Araştırma kapsamında hazırlanan ölçekler araştırma evrenini oluşturan 2314 kişi arasından 503 kişiye olasılıklı olmayan tesadüfi örnekleme yöntemi ile dağıtılmıştır. Bu kişilerden 326'sı Kişisel Bilgi Formu ve ölçekleri doldurarak geri iletmiştir. Bunlardan 18'i eksikliklerin çok fazla olması veya ölçeklerde birden fazla seçeneğin aynı anda işaretlenmesinden dolayı araştırmaya dâhil edilmemiştir. Sonuç olarak sağlıklı bir şekilde doldurulan 308 anketten elde edilen verilerle analizler yapılmıştır. Örneklemin evren büyüklüğüne oranı 0,13 olarak bulunmuştur.

\section{Veri Toplama Aracı ve Analiz Teknikleri}

Bu araştırmaya katılan infaz ve koruma memurlarının demografik özellikleri ve niteliklerini belirleyebilmek amacıyla araştırmacı tarafından hazırlanan Kişisel Bilgi Formu, katılımcıların iş doyum düzeylerini ölçmek için Minnesota İş Doyum Ölçeği (MDÖ), tükenmişlik düzeylerinin tespiti için ise Maslach Tükenmişlik Ölçeği (MTÖ) kullanılmıştır. 
Kişisel Bilgi Formu: Araştırmaya katılanların görev yaptıkları il ve kurum tipleri, yaş, cinsiyet, medeni hal, çocuk sayısı, eğitim durumu, hizmet süresi, kurumda yaptığ görev ve algılanan ekonomik düzey gibi bilgilerini toplamak amacıyla araştırmacı tarafından oluşturulmuştur.

Minnesota İş Doyum Ölçeği (MDÖ): Araştırma için yapılan literatür taraması sonucunda; infaz ve koruma memurlarının iş doyum düzeylerinin ölçülebilmesi için bu konuda en çok kullanılan ve bilinen ölçek olan Minnesota İş Doyum Ölçeğinin kullanılması uygun görülmüştür. MDÖ’nün alt boyutu olan içsel doyum; işin kendisi, işin sorumluluğu, bireyin iş yerindeki başarısı, diğerleri tarafından tanınma ve takdir edilmeyi, yükselme veya terfi sonucu görev değişikliği gibi işin içsel niteliği ile ilgili kişinin yaşadığı tatmin seviyesini ifade etmektedir. İçsel doyumu ölçen on iki sorudan elde edilen ortalama toplam içsel doyum puanıdır (Köroğlu, 2012). Diğer bir alt boyut olan dışsal doyum ise; yöneticilerin çalışma şekli, denetimi, astlarla olan ilişkileri, kurum politikaları, çalışılan ortamın fiziki durumu ve ücret gibi işin çevresine ilişkin faktörlerden oluşmaktadır. Dışsal doyum düzeyini ölçmeye yönelik sekiz sorudan elde edilen ortalama toplam dışsal doyum puanını vermektedir (Weiss vd., 1967).

Maslach Tükenmişlik Ölçeği (MTÖ): Araştırmada infaz ve koruma memurlarının tükenmişlik düzeylerinin değerlendirilmesi için Maslach ve Jackson tarafından 1981 yılında geliştirilen Maslach Tükenmişlik Ölçeği kullanılmıştır. MTÖ'de 22 soru yer almakta; Duygusal Tükenme, Duyarsızlaşma ve Kişisel Başarıda Düşme Hissi adı verilen üç alt boyuttan oluşmaktadır.

- Duygusal Tükenme: Bireylerin psikolojik anlamda ne düzeyde tükendiği ile,

- Duyarsızlaşma: Bireyin işi dolayısıyla karşılaştığı kişilere karşı geliştirdiği olumsuz tavır ve davranışlarla,

- Kişisel Başarı Hissi: Bireylerin sahip olduğu başarı hissinin düzeyi ile ilgilidir. 


\section{Verilerin Analizi}

İnfaz ve koruma memurlarına uygulanan form ve ölçekler araştırmac1 tarafından tek tek incelenmiş, geçersiz olanlar dişında kalanlar SPSS 20 programı aracılığıyla bilgisayar ortamına aktarılmıştır. Minnesota İş Doyum Ölçeği ve Maslach Tükenmişlik Envanteri için ayrı ayrı aritmetik ortalama, standart sapma ve yüzde hesabı yapılmıştır.

Literatürdeki araştırmaların çoğunda olduğu gibi araştırmadaki ölçeklerin güvenilirlik katsayılarının hesaplanmasında Cronbach Alfa güvenilirlik testi uygulanmıştır. Analizlerin sonucunda elde edilen Cronbach Alfa katsayısı 0 ile 1 arasında değişmektedir. Nunnally (1967) analizlerden anlamlı sonuçlar elde edilebilmesi için Cronbach Alfa katsayısının 0,70 ve üzerinde bir değer olması gerektiğini belirtmiş, alfa katsayısına bağlı ölçek güvenilirliğini aşağıdaki gibi yorumlamıştır (Nunnally, 1967):

\begin{tabular}{lll}
\hline ÖLÇEKLER & Soru Saysı & Cronbach Alfa Katsayısı \\
\hline İçsel Doyum & 12 & 0,883 \\
Dişsal Doyum & 8 & 0,837 \\
Genel İş Doyumu & 20 & 0,923 \\
Duygusal Tükenme & 9 & 0,892 \\
Duyarsılaşma & 5 & 0,762 \\
Kişisel Başarıda Düşme Hissi & 8 & 0,709 \\
\hline
\end{tabular}

Minnesota İş Doyum Ölçeğiyle tespit edilmek istenilen; genel iş doyumu, içsel ve dışsal doyum düzeylerini ölçen soruların analizinde elde edilen değerler istenilen aralıktadır. Tükenmişliğin tespiti amacıyla kullanılan Maslach Tükenmişlik Envanterine ait soruların analizlerinde bulunan Cronbach Alfa Katsayısı yine istenilen aralıkta çıkmıştır. Bulgular 


\begin{tabular}{|c|c|c|c|}
\hline Değişkenler & Demografik Özellikler & $\begin{array}{l}\text { Say1 } \\
(\mathrm{N}=308)\end{array}$ & $\begin{array}{l}\text { Yüzde } \\
(\% 100)\end{array}$ \\
\hline \multirow{2}{*}{ Cinsiyet } & Kadın & 33 & 10,7 \\
\hline & Erkek & 275 & 89,3 \\
\hline \multirow{3}{*}{ Yaş } & $20-29$ & 92 & 29,9 \\
\hline & $30-39$ & 151 & 49 \\
\hline & 40 ve üzeri & 65 & 21,1 \\
\hline \multirow{4}{*}{ Eğitim } & Lise & 59 & 19,2 \\
\hline & Ön Lisans & 66 & 21,4 \\
\hline & Lisans & 167 & 54,2 \\
\hline & Yüksek Lisans ve Üzeri & 16 & 5,2 \\
\hline \multirow{3}{*}{ Medeni Durum } & Evli & 219 & 71,1 \\
\hline & Bekâr & 88 & 28,6 \\
\hline & Eşi ölmüş/Boşanmış & 1 & 0,3 \\
\hline \multirow{2}{*}{ Unvan } & İKM & 299 & 97,1 \\
\hline & $\overline{\text { İKBM }}$ & 9 & 2,9 \\
\hline \multirow{5}{*}{ Çocuk Sayısı } & 0 & 133 & 43,2 \\
\hline & 1 & 75 & 24,4 \\
\hline & 2 & 77 & 25 \\
\hline & 3 & 20 & 6,5 \\
\hline & 4 ve üzeri & 3 & 1,0 \\
\hline \multirow{3}{*}{ Çalışılan Kurum } & Yüksek Güvenlikli Cezaevi (F Tipi) & 92 & 29,9 \\
\hline & Kapalı Cezaevi & 182 & 59,1 \\
\hline & Açık Cezaevi & 34 & 11,0 \\
\hline \multirow{3}{*}{ Çalışılan Birim } & Vardiya & 97 & 31,5 \\
\hline & Ani Müdahale, Mahkum Kabul ve Revir & 73 & 23,7 \\
\hline & İdari Kısımda Çalışanlar & 138 & 44,8 \\
\hline \multirow{2}{*}{$\begin{array}{l}\text { Ekonomik Düzey } \\
\text { Algısı }\end{array}$} & Kendisini Alt Gelir Grubunda Görenler & 174 & 56,5 \\
\hline & Kendisini Üst Gelir Grubunda Görenler & 134 & 43,5 \\
\hline \multirow{3}{*}{$\begin{array}{l}\text { Toplam Görev Sü- } \\
\text { resi }\end{array}$} & $1-4 Y_{1}$ & 107 & 34,7 \\
\hline & 5-9 Yil & 99 & 32,2 \\
\hline & 10 Yil ve Üzeri & 102 & 33,1 \\
\hline Mevcut Görev & $1-4 Y_{11}$ & 156 & 50,7 \\
\hline Yapilan Kurum- & 5-9 Y Yl & 103 & 33,4 \\
\hline daki Çalışma Yılı & 10 Yıl ve Üzeri & 49 & 15,9 \\
\hline
\end{tabular}

Araştırmaya Katılanların Işs Doyumu ve Tükenmişlik Düzeyleriyle İlgili Ortalama ve Standart Sapma Değerleri 
Tablo-2: İş Doyumu ve Tükenmişlik Düzeyleriyle İlgili Betimsel Veriler

\begin{tabular}{lccc}
\hline & $\mathrm{N}$ & $\overline{\boldsymbol{x}}$ (Ortalama) & Standart Sapma (S) \\
\hline İçsel Doyum & 308 & 2,7022 & 0,74612 \\
Dişsal Doyum & 308 & 2,4479 & 0,78686 \\
Genel İş Doyumu & 308 & 2,6005 & 0,71996 \\
Duygusal Tükenme & 308 & 3,3180 & 0,85346 \\
Duyarsızlaşma & 308 & 2,7091 & 0,88810 \\
Kişisel Başarı & 308 & 3,2420 & 0,62310 \\
\hline \multicolumn{1}{c}{ Tablo-2'deki } & veriler & incelendiğinde & araștırmaya katılan infaz ve
\end{tabular}

koruma memurlarının genel iş doyum düzeylerinin $(\bar{x}=2,6005<3)$ düşük olduğu görülmektedir. Bununla birlikte içsel doyum düzeyleri ( $\bar{x}=$ $2,7022<3)$ ve dişsal doyum düzeyleri $(\bar{x}=2,4479<3)$ ortalamanın altındadir.

İnfaz ve koruma memurlarının tükenmişlik düzeyleri incelendiğinde; duygusal tükenme değerlerinin yüksek $(\bar{x}=3,3180>3)$ ve duyarsızlaşma düzeylerinin ortalama değerin altında $(\bar{x}=2,7091<3)$ olduğu görülmektedir. Kişisel başarı hissi alt boyutu düzeyinde ise ortalamanın üzerinde oldukları ( $\bar{x}=3,2420>3$ ) oldukları tespit edilmiştir. Bir başka ifadeyle infaz ve koruma memurları sadece duygusal tükenme alt boyutunda tükenmişlik yaşamaktadır.

\section{Iş̧ Doyumu ve Tükenmişliğin Alt Boyutları Arasındaki Korelasyonlar}

Tablo-3: Genel İş Doyumu ve Alt Boyutları İle Tükenmişliğin Alt Boyutları Arasındaki Korelasyon Analizleri $(N=308)$

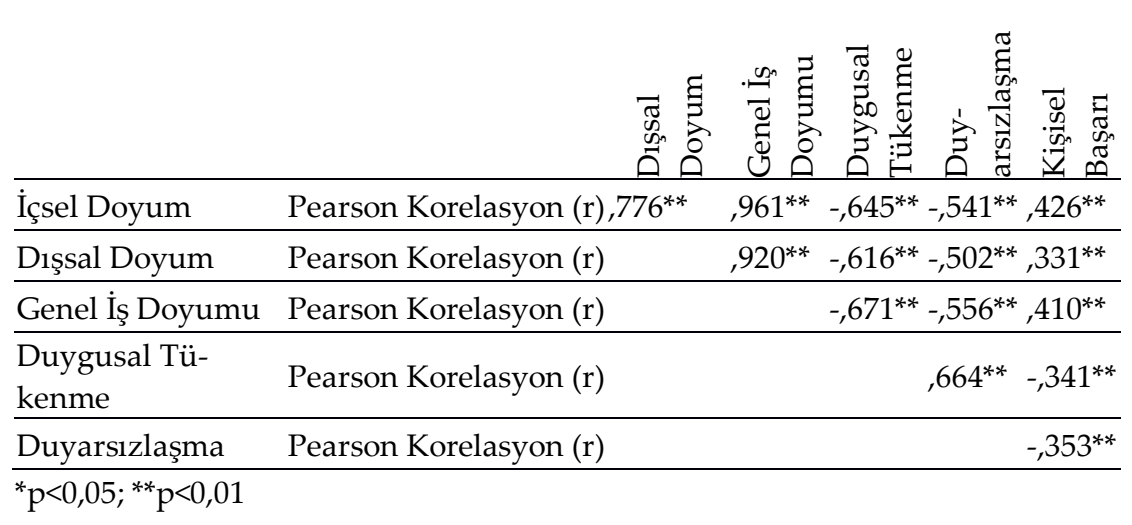


Genel iş doyumu ve alt boyutları arasındaki korelasyon analizlerine bakıldı̆̆ında; genel iş doyumu ile içsel ve dışsal doyum arasında kuvvetli ve pozitif ilişki olduğu görülmektedir. Yani infaz ve koruma memurlarının genel iş doyumunun artmasında her iki alt boyutta etkilidir. Tükenmişliğin kendi alt boyutları arasındaki korelasyonlara bakıldığında ise; duygusal tükenme ile duyarsızlaşma arasında kuvvetli ve pozitif, duygusal tükenme ve duyarsızlaşma ile kişisel başarı duygusu arasında kuvvetli ve negatif ilişki olduğu görülmektedir. Yani duygusal tükenme arttıkça bireyler duyarsızlaşmakta, kişisel başarı hisleri ise düşmektedir.

İş doyumu ve tükenmişlik arasındaki korelasyon analizi sonucunda ise şu bulgular tespit edilmiştir; bireylerin iş doyum düzeylerindeki artış duygusal tükenme ve duyarsızlaşma düzeylerinin azalmasını, kişisel başarı duygularının ise artmasını sağlamaktadır.

\section{Araştırmaya Katılanların İş doyumu ve Tükenmişlik Düzeylerinin} Ĕ̈itim Durumu Değişkenine Göre İncelenmesi

Tablo-4: Araştırmaya Katılanların İş Doyum Düzeylerinin Ĕ̆itim Durumlarına Göre Incelenmesine Yönelik Bulgular

\begin{tabular}{lllcccl}
\hline \multirow{2}{*}{ Boyutlar } & Öğrenim & $\mathrm{N}$ & $\overline{\boldsymbol{x}}$ & $\mathrm{S}$ & $\mathrm{t}$ & $\mathrm{p}$ \\
\hline Durçsel & Ön Lisans ve Altı & 125 & 2,8950 & 0,71820 & \multirow{2}{*}{3,830} & \multirow{2}{*}{$0,000^{* *}$} \\
Doyum & Lisans ve Üstü & 183 & 2,5706 & 0,73801 & & \\
\hline Dişsal & Ön Lisans ve Altı & 125 & 2,6193 & 0,76117 & \multirow{2}{*}{3,207} & \multirow{2}{*}{$0,001^{* *}$} \\
Doyum & Lisans ve Üstü & 183 & 2,3308 & 0,78465 & & \\
\hline Genel İş & Ön Lisans ve Altı & 125 & 2,7850 & 0,69346 & \multirow{2}{*}{3,798} & \multirow{2}{*}{$0,000^{* *}$} \\
Doyumu & Lisans ve Üstü & 183 & 2,4744 & 0,71228 & & \\
\hline
\end{tabular}

İş doyumu ve alt boyutlarının öğrenim durumu değişkenine göre incelendiği Tablo-4'den aşağıdaki sonuçlara ulaşılmaktadır:

İçsel doyum açısından; t306= 3,830; p= 0,000<0,05 olduğundan, ön lisans ve altı mezuniyet durumuna sahip olanlarla lisans ve üstü eğitim düzeyine sahip olanlar arasında anlamlı düzeyde fark vardır. Ön lisans ve 
altı öğrenim durumuna sahip olanların $(\bar{x}=2,8950)$ içsel doyumu, lisans ve üzeri öğrenim durumuna sahip olanlara $(\bar{x}=2,5706)$ göre anlamlı düzeyde daha fazladır.

Dişsal doyum açısından; $\mathrm{t} 306=3,207 ; \mathrm{p}=0,001<0,05$ olduğundan, ön lisans ve altı mezuniyet durumuna sahip olanlarla lisans ve üstü eğitim düzeyine sahip olanlar arasında anlamlı düzeyde fark vardır. Ön lisans ve altı öğrenim durumuna sahip olanların $(\bar{x}=2,6193)$ dışsal doyumu, lisans ve üzeri öğrenim durumuna sahip olanlara $(\bar{x}=2,3308)$ göre anlamlı düzeyde daha fazladır.

Genel iş doyumu açısından; $\mathrm{t306}=3,798 ; \mathrm{p}=0,000<0,05$ olduğundan, ön lisans ve altı mezuniyet durumuna sahip olanlarla lisans ve üstü eğitim düzeyine sahip olanlar arasında anlamlı düzeyde fark vardır. Ön lisans ve altı öğrenim durumuna sahip olanların $(\bar{x}=2,7850)$ genel iş doyumu, lisans ve üzeri öğrenim durumuna sahip olanlara $(\bar{x}=2,4744)$ göre anlamlı düzeyde daha fazladır.

Tablo-5: Araştırmaya Katılanların Tükenmişlik Düzeylerinin Eğitim Durumlarına Göre Incelenmesine Yönelik Bulgular

\begin{tabular}{|c|c|c|c|c|c|c|}
\hline Boyutlar & $\begin{array}{l}\text { Öğrenim } \\
\text { Durumu }\end{array}$ & $\mathrm{N}$ & $\bar{x}$ & $S$ & $\mathrm{t}$ & $\mathrm{p}$ \\
\hline Duygusal & Ön Lisans ve Altı & 125 & 3,1092 & 0,79794 & \multirow{2}{*}{$-3,617$} & \multirow{2}{*}{$0,000^{* *}$} \\
\hline Tükenme & Lisans ve Üstü & 183 & 3,4606 & 0,86283 & & \\
\hline \multirow{2}{*}{$\begin{array}{l}\text { Duy- } \\
\text { arsizlaşma }\end{array}$} & Ön Lisans ve Altı & 125 & 2,5856 & 0,88272 & \multirow{2}{*}{$-2,027$} & \multirow{2}{*}{$0,044^{*}$} \\
\hline & Lisans ve Üstü & 183 & 2,7934 & 0,88427 & & \\
\hline Kişisel & Ön Lisans ve Altı & 125 & 3,2997 & 0,63793 & \multirow[b]{2}{*}{1,345} & \multirow[b]{2}{*}{0,180} \\
\hline $\begin{array}{l}\text { Başarı } \\
\text { Hissi }\end{array}$ & Lisans ve Üstü & 183 & 3,2026 & 0,61139 & & \\
\hline
\end{tabular}

Tükenmişlik ve alt boyutlarının öğrenim durumu değişkenine göre incelendiği Tablo- 5 'ten aşağıdaki sonuçlara ulaşılmaktadır:

Duygusal tükenmişlik açısından; $\mathrm{t} 306=-3,617 ; \mathrm{p}=0,000<0,05$ olduğundan, ön lisans ve altı mezuniyet durumuna sahip olanlarla lisans ve üstü eğitim düzeyine sahip olanlar arasında anlamlı düzeyde fark vardır. Lisans ve üzeri öğrenim durumuna sahip olanların $(\bar{x}=3,4606)$ duygusal 
tükenmişliği, ön lisans ve altı öğrenim durumuna sahip olanlara $(\bar{x}=$ $3,1092)$ göre anlamlı düzeyde daha fazladır.

Duyarsızlaşma açısından; t306= -2,027; p= 0,044<0,05 olduğundan, ön lisans ve altı mezuniyet durumuna sahip olanlarla lisans ve üstü eğitim düzeyine sahip olanlar arasında anlamlı düzeyde fark vardır. Lisans ve üzeri öğrenim durumuna sahip olanların $(\bar{x}=2,7934)$ duyarsızlaşma düzeyi, ön lisans ve altı öğrenim durumuna sahip olanlara $(\bar{x}=2,5856)$ göre anlamlı düzeyde daha fazladır. Kişisel başarı açısından ise t306= 1,345; $\mathrm{p}=0,180>0,05$ değerine göre öğrenim durumu anlamlı fark yaratmamaktadır.

\section{Araştırmaya Katılanların Tükenmişlik Düzeylerinin Medeni Durum Değişkenine Göre İncelenmesi}

Tablo-6: Araştırmaya Katılanların Tükenmişlik Düzeylerinin Medeni Durumlarına Göre Incelenmesine Yönelik Bulgular

\begin{tabular}{|c|c|c|c|c|c|c|}
\hline Boyutlar & $\begin{array}{l}\text { Medeni } \\
\text { Durum }\end{array}$ & $\mathrm{N}$ & $\bar{x}$ & $S$ & $\mathrm{t}$ & $\mathrm{p}$ \\
\hline \multirow{2}{*}{$\begin{array}{l}\text { Duygusal } \\
\text { Tükenme }\end{array}$} & Evli & 219 & 3,3196 & 0,81407 & \multirow{2}{*}{0,051} & \multirow{2}{*}{0,960} \\
\hline & Bekar-Boşanmış & 89 & 3,3141 & 0,94834 & & \\
\hline \multirow{2}{*}{$\begin{array}{l}\text { Duy- } \\
\text { arsizlaşma }\end{array}$} & Evli & 219 & 2,6877 & 0,86352 & \multirow{2}{*}{$-0,663$} & \multirow{2}{*}{0,508} \\
\hline & Bekar-Boşanmış & 89 & 2,7618 & 0,94889 & & \\
\hline \multirow{2}{*}{$\begin{array}{l}\text { Kişisel Başarı } \\
\text { Hissi }\end{array}$} & Evli & 219 & 3,2899 & 0,61995 & \multirow{2}{*}{2,127} & \multirow{2}{*}{0,034} \\
\hline & Bekar-Boşanmış & 89 & 3,1242 & 0,61856 & & \\
\hline
\end{tabular}

Tükenmişlik alt boyutlarının medeni durum değişkenine göre ele alındığı Tablo-6'dan çıkan sonuçlar aşağıdaki gibidir:

Kişisel Başarı Hissi açısından; t306 = 2,127; p= 0,034<0,05 bulgusuna göre evli olanlar ve bekar veya boşanmış olanlar arasında anlamlı düzeyde fark vardır. Evli olanların $(\bar{x}=3,2899)$ kişisel başarı hissi, bekar veya boşanmış olanlara $(\bar{x}=3,1242)$ göre anlamlı düzeyde daha fazladır. 
Bir başka ifadeyle kişisel başarı alt boyutunda evli olanlar daha az tükenmişlik yaşamaktadırlar. Tükenmişliğin diğer iki alt boyutunda ise medeni durum anlamlı fark oluşturmamaktadır.

\section{Araştırmaya Katılanların İş Doyum Düzeylerinin Çalıştıkları Cezaevine Göre İncelenmesine Yönelik Bulgular}

Tablo-7: F Tipi Yüksek Güvenlikli Cezaevlerinde Çalışan İnfaz Koruma Memurları İle Diğer Cezaevlerinde Çalışan İnfaz Koruma Memurlarının İş Doyum Düzeylerinin Incelenmesine Yönelik Bulgular

\begin{tabular}{lllllll}
\hline Boyutlar & Cezaevi & $\mathrm{N}$ & $\overline{\boldsymbol{x}}$ & $\mathrm{S}$ & $\mathrm{t}$ & $\mathrm{p}$ \\
\hline İçsel & F Tipi & 92 & 2,6797 & 0,77498 & \multirow{2}{*}{0,346} & \multirow{2}{*}{0,730} \\
Doyum & Diğerleri & 216 & 2,7119 & 0,73512 & & \\
\hline Dişsal & F Tipi & 92 & 2,5899 & 0,76139 & \multirow{2}{*}{2,078} & \multirow{2}{*}{$0,039^{*}$} \\
Doyum & Diğerleri & 216 & 2,3874 & 0,79146 & & \multirow{2}{*}{0,486} \\
\hline Genel İs & F Tipi & 92 & 2,6443 & 0,73503 & \multirow{2}{*}{0,697} & \multirow{2}{*}{ Doyumu } \\
Diğgerleri & 216 & 2,5818 & 0,71435 & & \\
\hline
\end{tabular}

İş doyumu ve alt boyutlarının, çalışılan cezaevi tipine göre ele alındığı Tablo-7'de sadece dişsal doyum açısından anlamlı fark bulunmuştur. Dişsal doyum açısından; $\mathrm{t306}=2,078 ; \mathrm{p}=0,039<0,05$ bulgusuna göre $\mathrm{f}$ tipi cezaevlerinde çalışanlar ile diğer cezaevlerinde çalışanlar arasında anlamlı düzeyde fark vardır. F tipi cezaevlerinde çalışanların $(\bar{x}=$ $2,5899)$ dişsal doyum düzeyleri, diğer cezaevlerinde çalışanlara ( $\bar{x}=$ $2,3874)$ göre anlamlı düzeyde daha fazladır. Bir başka ifadeyle dışsal doyum alt boyutunda f tipi cezaevlerinde çalışanlar daha yüksek düzeyde doyum sağlamaktadır.

Araştırmaya Katılanların İş Doyum ve Tükenmişlik Düzeylerinin Algıladıkları Ekonomik Durumlarna Göre İncelenmesine Yönelik Bulgular

Araştırmanın bu bölümünde infaz ve koruma memurlarının algıladıkları ekonomik düzeylerine göre iş doyumu ve tükenmişlik düzeylerine ilişkin bulgular verilecektir. 
Tablo-8: Araştırmaya Katılanların Algıladıkları Ekonomik Durumlarına Göre İş Doyum Düzeylerinin İncelenmesine Yönelik Bulgular

\begin{tabular}{|c|c|c|c|c|c|c|}
\hline Boyutlar & $\begin{array}{l}\text { Algilanan } \\
\text { Ekonomik du- } \\
\text { rum }\end{array}$ & $\mathbf{N}$ & $\bar{x}$ & $\mathrm{~S}$ & $\mathbf{t}$ & $\mathbf{p}$ \\
\hline \multirow{2}{*}{$\begin{array}{l}\text { Duygusal } \\
\text { Tükenme }\end{array}$} & Alt Gelir Grubu & 174 & 3,5032 & 0,807 & \multirow[b]{2}{*}{4,472} & \multirow[b]{2}{*}{, $001^{* *}$} \\
\hline & $\begin{array}{l}\text { Üst } \quad \text { Gelir } \\
\text { Grubu }\end{array}$ & 134 & 3,0775 & 0,854 & & \\
\hline \multirow{2}{*}{$\begin{array}{l}\text { Duy- } \\
\text { arsizlaşma }\end{array}$} & Alt Gelir Grubu & 174 & 2,9149 & 0,895 & \multirow[b]{2}{*}{4,799} & \multirow[b]{2}{*}{, $001^{* *}$} \\
\hline & $\begin{array}{l}\text { Üst } \quad \text { Gelir } \\
\text { Grubu }\end{array}$ & 134 & 2,4418 & 0,806 & & \\
\hline \multirow{2}{*}{$\begin{array}{l}\text { Kişisel } \\
\text { Hissi }\end{array}$} & Alt Gelir Grubu & 174 & 3,2008 & 0,644 & \multirow[b]{2}{*}{$-1,323$} & \multirow[b]{2}{*}{0,187} \\
\hline & $\begin{array}{l}\text { Üst } \quad \text { Gelir } \\
\text { Grubu }\end{array}$ & 134 & 3,2954 & 0,591 & & \\
\hline
\end{tabular}

İş doyumu ve alt boyutlarının, ekonomik algı değişkenine göre ele alındığı Tablo-8'den çıkan sonuçlar aşağıdaki gibidir:

İçsel doyum açısından; t306 $=-4,724 ; p=0,000<0,05$ bulgusuna göre ekonomik anlamda kendisini alt gelir grubu içinde görenler ile üst gelir grubu arasında görenler arasında anlamlı düzeyde fark vardır. Kendisini alt gelir grubunda gören infaz ve koruma memurlarının içsel doyum düzeyi $(\bar{x}=2,5318)$, kendisini üst gelir grubunda görenlere göre $(\bar{x}=2,9236)$ anlamlı düzeyde daha düşüktür. Bir diğer ifadeyle ekonomik algı açısından kendisini üst gelir grubunda görenlerin içsel doyumu anlamlı düzeyde daha fazladır.

Dişsal doyum açısından; $\mathrm{t} 306=-4,999 ; \mathrm{p}=0,000<0,05$ bulgusuna göre ekonomik anlamda kendini alt gelir grubu içinde görenler ile üst gelir grubu arasında görenler arasında anlamlı düzeyde fark vardır. Kendisini alt gelir grubunda gören infaz ve koruma memurlarının dişsal doyum düzeyi $(\bar{x}=2,2584)$, kendisini üst gelir grubunda görenlere göre $(\bar{x}=2,6939)$ anlamlı düzeyde daha düşüktür. Bir diğer ifadeyle ekonomik algı açısından kendisini üst gelir grubunda görenlerin dışsal doyumu anlamlı düzeyde daha fazladır. 
Genel iş doyumu açısından; $\mathrm{t} 306=-5,152 ; \mathrm{p}=0,000<0,05$ bulgusuna göre ekonomik anlamda kendini alt gelir grubu içinde görenler ile üst gelir grubu arasında görenler arasında anlamlı düzeyde fark vardır. Kendisini alt gelir grubunda gören infaz ve koruma memurlarının genel iş doyum düzeyi $(\bar{x}=2,4223)$, kendisini üst gelir grubunda görenler göre $(\bar{x}=2,8319)$ anlamlı düzeyde daha düşüktür. Bir diğer ifadeyle ekonomik algı açısından kendisini üst gelir grubunda görenlerin gene iş doyumu anlamlı düzeyde daha fazladır.

Tablo-9: Araştırmaya Katılanların Algıladıkları Ekonomik Durumlarına Göre Tükenmişlik Düzeylerinin Incelenmesine Yönelik Bulgular

\begin{tabular}{|c|c|c|c|c|c|c|}
\hline Boyutlar & $\begin{array}{l}\text { Algılanan } \\
\text { Ekonomik du- } \\
\text { rum }\end{array}$ & $\mathbf{N}$ & $\bar{x}$ & $S$ & $\mathbf{t}$ & $\mathbf{p}$ \\
\hline \multirow[b]{2}{*}{ İçsel Doyum } & Alt Gelir Grubu & 174 & 2,5318 & 0,713 & \multirow[b]{2}{*}{$-4,724$} & \multirow[b]{2}{*}{, $001^{* *}$} \\
\hline & $\begin{array}{l}\text { Üst } \quad \text { Gelir } \\
\text { Grubu }\end{array}$ & 134 & 2,9236 & 0,731 & & \\
\hline \multirow[b]{2}{*}{ Dişsal Doyum } & Alt Gelir Grubu & 174 & 2,2584 & 0,745 & \multirow[b]{2}{*}{$-4,999$} & \multirow[b]{2}{*}{, $001^{* *}$} \\
\hline & $\begin{array}{l}\text { Üst } \\
\text { Grubu }\end{array}$ & 134 & 2,6939 & 0,773 & & \\
\hline \multirow[b]{2}{*}{$\begin{array}{l}\text { Genel } \\
\text { Doyumu }\end{array}$} & Alt Gelir Grubu & 174 & 2,4223 & 0,681 & \multirow[b]{2}{*}{$-5,152$} & \multirow[b]{2}{*}{001} \\
\hline & $\begin{array}{l}\text { Üst } \quad \text { Gelir } \\
\text { Grubu }\end{array}$ & 134 & 2,8319 & 0,704 & & \\
\hline
\end{tabular}

Tükenmişlik ve alt boyutlarının, ekonomik algı değişkenine göre ele alındığı Tablo-9'dan çıkan sonuçlar aşağıdaki gibidir:

Duygusal tükenme açısından; $\mathrm{t} 306=4,472 ; \mathrm{p}=0,000<0,05$ bulgusuna göre ekonomik anlamda kendisini alt gelir grubu içinde görenler ile üst gelir grubu arasında görenler arasında anlamlı düzeyde fark vardır. Kendisini alt gelir grubunda gören infaz ve koruma memurlarının duygusal tükenme düzeyi $(\bar{x}=3,5032)$, kendisini üst gelir grubunda görenlere göre $(\bar{x}=3,0775)$ anlamlı düzeyde daha yüksektir. Bir diğer ifadeyle ekonomik algı açısından kendisini üst gelir grubunda görenler anlamlı düzeyde daha az tükenmişlik yaşamaktadırlar. 
Duyarsızlaşma açısından; $\mathrm{t} 306=4,799 ; \mathrm{p}=0,000<0,05$ bulgusuna göre ekonomik anlamda kendini alt gelir grubu içinde görenler ile üst gelir grubu arasında görenler arasında anlamlı düzeyde fark vardır. Kendisini alt gelir grubunda gören infaz ve koruma memurlarının duyarsızlaşma düzeyi $(\bar{x}=2,9149)$, kendisini üst gelir grubunda görenlere göre $(\bar{x}=2,4418)$ anlamlı düzeyde daha yüksektir. Yani ekonomik algı açısından kendisini alt gelir grubunda görenler işyerinde örgüt ve çevresine karşı anlamlı düzeyde daha fazla duyarsızlık yaşamaktadırlar.

Araştırmaya Katılanların Yaşlarının, İş Doyumu ve Tükenmişlik Düzeyine Etkilerinin İncelenmesine Yönelik Bulgular

Tablo-10: Yaş İle İş Doyumu ve Tükenmişlik Alt Boyutları Arasındaki Korelasyonl $N=308$

\begin{tabular}{|c|c|c|c|c|c|c|c|}
\hline & & $\begin{array}{l}\text { İçsel } \\
\text { Doyum }\end{array}$ & $\begin{array}{l}\text { Dişsal } \\
\text { Doyum }\end{array}$ & $\begin{array}{l}\text { Genel İş } \\
\text { Doyumu }\end{array}$ & $\begin{array}{l}\text { Duygusal } \\
\text { Tükenme }\end{array}$ & $\begin{array}{l}\text { Duy- } \\
\text { arsizlaşma }\end{array}$ & $\begin{array}{l}\text { Kişisel } \\
\text { Başarı Hissi }\end{array}$ \\
\hline \multirow{2}{*}{ Yaş } & $\mathrm{r}$ & 0,089 & $0,152^{* *}$ & $0,122^{*}$ & $-0,140^{*}$ & $-0,133^{*}$ & $0,159^{* *}$ \\
\hline & $\mathrm{p}$ & 0,120 & 0,008 & 0,033 & 0,014 & 0,020 & 0,005 \\
\hline
\end{tabular}

Tablo-10'da ortaya çıkan korelasyon analizi sonucunda; yaş ile iş doyumunun dışsal doyum ve genel iş doyumu; yaş ile tükenmişliğin duygusal tükenme, duyarsızlaşma ve kişisel başarı hissi alt boyutları arasında ilişki olduğu tespit edilmiştir.

Bu ilişkiler aşağıdaki gibidir:

Araştırmaya katılanların yaşı ve dışsal doyum puanları arasında güçlü bir ilişki vardır $(\mathrm{p}<0,01)$. Bu ilişki pozitif yönlüdür $(\mathrm{r}=0,152)$. Bu sebeple infaz ve koruma memurlarının yaşı arttıkça dışsal doyum puanı da artmaktadır. Araştırmaya katılanların yaşı ve genel iş doyum puanları arasında ilişki vardır $(p<0,05)$. Bu ilişki pozitif yönlüdür $(r=0,122)$. Bu sebeple infaz ve koruma memurlarının yaşı arttıkça genel iş doyumu da artmaktadır. 
Araştırmaya katılanların yaşı ve duygusal tükenme puanları arasında ilişki vardır $(p<0,05)$. Bu ilişki negatif yönlüdür $(r=-0,140)$. Bu sebeple infaz ve koruma memurlarının yaşı arttıkça duygusal tükenme puanı düşmektedir.

Araştırmaya katılanların yaşı ve duyarsızlaşma puanları arasında ilişki vardır $(p<0,05)$. Bu ilişki negatif yönlüdür $(r=-0,133)$. Bu sebeple infaz ve koruma memurlarının yaşı arttıkça daha az duyarsızlaşma yaşamaktadırlar. Araştırmaya katılanların yaşı ve kişisel başarı hisleri arasında güçlü bir ilişki vardır $(\mathrm{p}<0,05)$. Bu ilişki pozitif yönlüdür $(\mathrm{r}=0,159)$. Bu sebeple infaz ve koruma memurlarının yaşı arttıkça kişisel başarı hisleri artmaktadir.

Araştırmaya Katılanların Toplam Çalışma Süresinin, İş Doyumu İle Tükenmişlik Düzeyine Etkilerinin İncelenmesine Yönelik Bulgular

Tablo-11: Araştırmaya Katılanların Toplam Çalışma Süresi İle İş Doyumu ve Tükenmişlik Düzeyleri Arasındaki Korelasyon Analizi N=308

\begin{tabular}{|c|c|c|c|c|c|c|c|}
\hline & & $\begin{array}{l}\text { İçsel } \\
\text { Doyum }\end{array}$ & $\begin{array}{l}\text { Dişsal } \\
\text { Doyum }\end{array}$ & $\begin{array}{l}\text { Genel } \\
\text { İş Doyumu }\end{array}$ & $\begin{array}{l}\text { Duygusal } \\
\text { Tükenme }\end{array}$ & $\begin{array}{l}\text { Duyarsiz } \\
\text { laşma }\end{array}$ & $\begin{array}{l}\text { Kişisel Başarı } \\
\text { Hissi }\end{array}$ \\
\hline Toplam & $\mathrm{r}$ & 0,062 & 0,106 & 0,085 & $-0,060$ & $-0,118^{*}$ & $0,158^{* *}$ \\
\hline Görev & $p$ & 0,280 & 0,062 & 0,137 & 0,296 & 0,038 & 0,006 \\
\hline
\end{tabular}

Yapılan korelasyon analizleri sonucunda ortaya çıkan bulgular aşağıdaki gibidir:

Toplam görev süresi ile duyarsızlaşma arasında anlamlı bir ilişki vardır $(p<0,05)$. Bu ilişki negatif yönlüdür $(r=-0,118)$. Bu nedenle infaz ve koruma memurlarının toplam görev süresi arttıkça duyarsızlaşma düzeyleri azalmaktadır. Bir başka ifadeyle çalışma yılının artmasıyla birlikte çalışanlar hizmet alanların taleplerine ve iş arkadaşlarına karşı daha duyarlı bir hale gelmektedir.

Toplam görev süresi ile kişisel başarı hissi arasında güçlü ve anlamlı bir ilişki vardır $(\mathrm{p}<0,01)$. Bu ilişki pozitif yönlüdür $(\mathrm{r}=0,158)$. Bu nedenle infaz ve koruma memurlarının toplam görev süresi arttıkça kişisel başarı 
hisleri artmaktadır. Bir başka ifadeyle mesleğin ilk yıllarında infaz ve koruma memurlarının başarı hisleri düşükken ilerleyen yıllarla birlikte kişisel başarı hislerinde artış olmaktadır.

\section{Tartışma, Sonuç ve Öneriler}

Bu bölümde araştırmanın örneklemini oluşturan infaz ve koruma memurlarının iş doyumu ve tükenmişlik seviyeleriyle ilgili elde edilen bulgulardan yola çıkılarak tartışma ve yorumlar yapılmıştır. Literatür taramasında infaz ve koruma memurlarıyla ilgili çalışma sayısının az olması nedeniyle yorumlar bu sinırlılık çerçevesinde yapılmış, bulgular bölümünde elde edilen verilerin sırasına sadık kalınmıştır.

Araştırmaya katılan infaz ve koruma memurlarının genel iş doyum düzeylerinin düşük olduğu görülmüş, iş doyumunun alt boyutları olan; içsel ve dışsal doyum düzeylerinin de ortalamanın altında olduğu tespit edilmiştir. Bu durum infaz ve koruma memurlarının hem yaptıkları iş ile ilgili hem de kurum politikaları, idarecilerle olan ilişkileri ve çalıştıkları ortamın fiziki durumu ile ilgili etmenlerden doyumsuz olduklarını göstermektedir. Literatür incelemesinde Aktaş (2009)'ın benzer biçimde Bolu F Tipi Yüksek Güvenlikli Kapalı Cezaevinde çalışan infaz ve koruma memurlarının genel iş doyum düzeylerinin düşük olduğu bulgusuna ulaştı̆̆ görülmektedir.

Tükenmişlik seviyesi ile ilgili olarak infaz ve koruma memurlarının; duygusal tükenme düzeylerinin yüksek, duyarsızlaşma düzeylerinin ortalama değerin altında ve kişisel başarı hislerinin ortalama değerin üzerinde olduğu bulgusuna ulaşılmıştır. Bir başka ifadeyle infaz ve koruma memurları, sadece duygusal tükenme alt boyutunda tükenmişlik yaşamaktadır. Bu bulgunun dikkatle ele alınması gereklidir. Çünkü Maslach'a göre duygusal tükenme, tükenmişliğin temeli ve en önemli belirtisidir (Cordes ve Dougherty, 1993). Duygusal tükenme kişilerin kendisini fiziksel ve duygusal yönden yıpranmış, enerjisini tüketmiş ve 
bu enerji kaynaklarını asla dolduramayacaklarını hissetmeleriyle ilgilidir. Araştırmada her ne kadar infaz ve koruma memurlarının duyarsızlaşma ve kişisel başarıda düşme hissi yaşamadıkları bulgusu elde edilse de, tükenmişliğin ilk aşaması olan duygusal tükenme düzeylerinin yüksek çıkması bu konuda gerekli önlemlerin alınması konusunda ipuçları vermektedir. Literatür incelemesinde infaz ve koruma memurlarının tükenmişlik düzeylerini ölçen herhangi bir araştırmaya rastlanmamıştır.

$\mathrm{Bu}$ çalışmada iş doyumu ve tükenmişlik ile eğitim durumu arasında anlamlı ilişkiler bulunmuştur. İş doyumunun alt boyutlarından içsel doyum açısından; ön lisans ve altı öğrenim durumuna sahip olanların iş doyumu, lisans ve üzeri öğrenim durumuna sahip olanlara göre anlamlı düzeyde daha fazladır. Dışsal doyum açısından; ön lisans ve altı öğrenim durumuna sahip olanların dışsal doyumu, lisans ve üzeri öğrenim durumuna sahip olanlara göre anlamlı düzeyde daha fazladır. Genel iş doyumu açısından; ön lisans ve altı öğrenim durumuna sahip olanların genel iş doyumu, lisans ve üzeri öğrenim durumuna sahip olanlara göre anlamlı düzeyde daha fazladır. İnfaz ve koruma memurlarının eğitim durumu ile tükenmişlik düzeyi arasında da anlamlı ilişkiler vardır. Tükenmişliğin duygusal tükenmişlik alt boyutu açısından; Lisans ve üzeri öğrenim durumuna sahip olanların duygusal tükenmişliği, ön lisans ve altı öğrenim durumuna sahip olanlara göre anlamlı düzeyde daha fazladır. Duyarsızlaşma açısından; lisans ve üzeri öğrenim durumuna sahip olanların duyarsızlaşma düzeyi, ön lisans ve altı öğrenim durumuna sahip olanlara göre anlamlı düzeyde daha fazladır. Kişisel başarı hissi açısından ise eğitim düzeyi değişkenine göre anlamlı düzeyde fark bulunmamaktadır. Sonuç olarak infaz ve koruma memurlarında eğitim düzeyindeki artış iş doyum düzeyini azaltmakta, tükenmişliğin duygusal tükenme ve duyarsızlaşma boyutlarında ise artışa neden olmaktadır. Bireylerin eğitim düzeyindeki artış, iş ve sosyal yaşamlarında daha büyük beklentiler içinde olmasına yol açar. Zaman içerisinde beklentilerin 
yüksek olması ve bu beklentilere ulaşılamaması bireylerde iş doyumsuzluğuna ve tükenmişliğe neden olmaktadır.

Maslach 2001 yılında yapmış olduğu çalışmasında eğitim düzeyi yüksek çalışanların işyerlerinde daha fazla tükenmişlik yaşadığını tespit etmiştir. Bireylerin eğitim düzeyleri arttıkça örgüt içerisinde daha idealist olması, fazla sorumluluk alması ve işi ile ilgili beklentilerinin yüksek olması tükenmişliğin artmasına sebep olarak gösterilmektedir (Sat, 2011). Literatür araştırmasında tükenmişlikle öğrenim durumu ilişkisine ilişkin yapılan çalışmalarda farklı sonuçlarla karşılaşılsa da genel olarak öğrenim düzeyi arttıkça tükenmişliğin arttığı bulgusuna ulaşılmıştır. Dursun'un 2000 yılında ve Peker'in 2002 yılında yaptığı çalışmalar öğrenim durumunun yükselmesi durumunda tükenmişliğin anlamlı şekilde arttığını göstermektedir.

Araştırmada medeni durum değişkeni ile tükenmişliğin iki alt boyutu duygusal tükenme ve duyarsızlaşma arasında anlamlı bir ilişki olmadığı tespit edilmiştir. Ancak kişisel başarı hissi alt boyutu açısından; evli olanların kişisel başarı hissi, bekar veya boşanmış olanlara göre anlamlı düzeyde daha fazladır. Bir başka ifadeyle kişisel başarı alt boyutunda evli olanlar daha az tükenmişlik yaşamaktadırlar. Kişisel başarı hissi alt boyutunda evli olanların daha az tükenmişlik yaşaması, ailelerinden aldığı destek sayesinde olaylara daha realist bakmaları ve hizmet alanlar ile iş çevresinden olumsuz geri bildirim alsa bile bu durumu tolere edebildiği biçiminde yorumlanabilir.

Araştırmada çalışılan cezaevi tipine göre infaz ve koruma memurlarının iş doyumu ve tükenmişlik düzeylerinin bazı alt boyutları arasında anlamlı farklar olduğu görülmüştür. Çalışmada içeride kalan tutukluhükümlüprofili açısından devlet politikası kapsamında, en yüksek güvenlik donanımlarına ve özel fiziki yapıya sahip F tipi cezaevleriyle diğer cezaevlerinde çalışan infaz ve koruma memurlarının iş doyumu ve tükenmişlik düzeyleri karşılaştırılmıştır. Elde edilen bulgulara göre, iş doyumu alt boyutlarından yalnızca dışsal doyum düzeyinde anlamlı 
farklar ortaya çıkmıştır. Buna göre F tipi cezaevlerinde görev yapan infaz ve koruma memurlarının dişsal doyum düzeyleri diğer cezaevlerinde çalışanlara göre anlamlı düzeyde daha yüksek çıkmıştır. Görev yapılan cezaevi açısından tükenmişlik düzeyleri arasındaki farklara bakıldığında ise tükenmişliğin üç alt boyutunda da cezaevi tipine göre infaz ve koruma memurları arasında anlamlı farklar çıkmamıştır.

$\mathrm{Bu}$ sonuç araştırma açısından dikkat çekicidir ve beklentinin tam tersi sonuçlar ortaya çıkmıştır. Türkiye'de F tipi cezaevlerinin en yüksek güvenlik donanımlarıla çevrili olması, içeride kalan tutukluhükümlülerin büyük oranda siyasi, terör ve örgütlü suçlardan dolayı tutuklu ve hükümlü olmaları, yerli ve yabancı medya mensupları ve sivil toplum kuruluşları tarafından F tipi cezaevlerinin sürekli gündemde tutulmasının çalışanlar üzerinde bir baskı yarattı̆̆ düşünülmektedir. Bu durumun F tipi cezaevlerinde çalışan infaz ve koruma memurları üzerinde olumsuz etkiler yarattığı ve diğer cezaevi çalışanlarına göre daha fazla iş doyumsuzluğu ve tükenmişlik yaratacağı düşünülmektedir. Ancak araştırma farklı sonuçlar vermiştir. Hatta kurumdaki yöneticilerin çalışma şekli, denetimi, astlarla olan ilişkileri, kurum politikaları, çalışılan ortamın fiziki durumu gibi faktörleri içine alan dışsal doyum düzeyi F tipi cezaevlerinde çalışan infaz ve koruma memurlarında daha yüksektir.

Çalışmada infaz ve koruma memurlarının kendileriyle ilgili ekonomik algılarının iş doyumu ve tükenmişlik düzeylerinde anlamlı farklar yarattığı sonucuna ulaşılmıştır. Bu kapsamda içsel doyum, dışsal doyum ve genel iş doyumu açısından kendisini alt gelir grubunda gören infaz ve koruma memurlarının doyum düzeylerinin, kendisini üst gelir grubunda görenlere göre anlamlı düzeyde daha düşük olduğu saptanmıştır. Tükenmişlik düzeyi alt boyutlarında ise kendisini ekonomik anlamda alt gelir grubunda görenlerin daha çok duygusal tükenme yaşadığı, örgüt ve çevresindekilere karşı daha fazla duyarsızlaştığı belirlenmiştir. Kişisel başarı hissi alt boyutunda ise ekonomik anlamda kendini alt gelir grubu 
içinde görenler ile üst gelir grubu arasında görenler arasında anlamlı düzeyde bir farklılık bulunmadığı belirlenmiştir.

Bu sonuç infaz ve koruma memurlarının kendileriyle ilgili ekonomik algılarının iş doyumu ve tükenmişlik düzeyleri üzerinde çok önemli etkisi olduğu şeklinde yorumlanmaktadır. Literatür araştırması ücretle iş doyumu ve tükenmişlik düzeyi arasındaki ilişkilerin incelendiği çalışmalarda farklı sonuçlar elde edildiğini göstermektedir. Atlandı (2010) tarafından çağrı merkezi çalışanları üzerinde yapılan araştırmada, iş doyumu ve alt boyutlarıyla çalışanın ekonomik algısı arasında herhangi bir ilişki olmadığı tespit edilmiştir. Aynı araştırmada ekonomik algı değişkeninin tükenmişliği bütün alt boyutlarında etkilediği sonucuna varılmıştır (Atlandı, 2010).

Araştırmada infaz ve koruma memurlarının yaş değişkeniyle iş doyumu ve tükenmişlik düzeyleri arasında ilişki olup olmadığ 1 incelenmiş, yaş değişkeninin iş doyumu ve tükenmişliği içsel doyum hariç tüm alt boyutlarda anlamlı düzeyde etkilediği tespit edilmiştir. Buna göre infaz ve koruma memurlarında yaş arttıkça dışsal doyum ve genel doyum düzeyi artmaktadır. Tükenmişlik bazında ise yaşın yükselmesi duygusal tükenmeyi ve duyarsızlaşmayı azaltmakta, kişisel başarı hissinin ise yükselmesini sağlamaktadır.

İnfaz ve koruma memurlarının toplam çalışma süresiyle iş doyum düzeyleri arasında anlamlı ilişki olmadığı̆, ancak tükenmişliğin duyarsızlaşma ve kişisel başarı hissi alt boyutlarıyla toplam çalışma süresi arasında anlamlı ilişki olduğu görülmüştür. Araştırma sonuçları infaz ve koruma memurlarının toplam görev süresi arttıkça duyarsızlaşma düzeylerinin azaldığını göstermiştir. Bir başka ifadeyle çalışma yılının artmasıyla birlikte infaz ve koruma memurları, tutuklu-hükümlülerin taleplerine ve iş arkadaşlarına karşı daha duyarlı bir hale gelmektedir. Tükenmişliğin kişisel başarı hissi alt boyutunda ise infaz ve koruma memurlarının toplam görev süresi arttıkça kişisel başarı hislerinin arttığı bulgusuna ulaşılmıştır. 
Araştırma sonuçları çerçevesinde cezaevi idareleri ile Adalet Bakanlığı yöneticilerine bazı önerilerimiz bulunmaktadır:

İnfaz ve koruma memurlarıyla ilgili yapılan ve yok denecek kadar az olan iş doyumu ve tükenmişlik araştırmalarının daha fazla yapılması, sinsi seyreden ve çoğunlukla bireyler ve yöneticiler tarafından algılanamayan rahatsızlığın teşhisi ve erken dönemde baş edilebilmesinde önem arz etmektedir.

Cezaevlerinde çalışan infaz koruma memurlarında; eğitim seviyesi yüksek olanların iş doyumu ve tükenmişlik sendromuna daha yatkın olması, cezaevlerindeki kariyer planlamalarının yeniden gözden geçirilmesi gerektiğine işaret etmektedir. Bu kapsamda cezaevlerindeki personel birimlerinin insan kaynakları bölümlerine dönüştürülmesi ve verimli işleyen bir sisteme sahip olması gerekir. Örneğin; iş doyumsuzluğu ve tükenmişlik yaşadığı tespit edilen infaz ve koruma memuru, cezaevlerinde bilgi ve yeteneklerini kullanabileceği farklı birimlere yönlendirilebilir. $\mathrm{Bu}$ ise memurların iş doyumu ve motivasyon düzeylerini takip eden etkin bir insan kaynakları yönetimiyle sağlanabilir. Kendisini geliştirmek ve görevde yükselmek isteyen infaz ve koruma memurlarına yeterli olanaklar sağlanmalıdır. Gelişme sağlayan memurların örgütten kopmamaları için öğrendikleri bilgi ve becerileri kullanabilecekleri ortamlar yaratılmalıdır.

Çalışmada ekonomik durumun infaz ve koruma memurlarının iş doyumu ve tükenmişlik düzeylerini önemli ölçüde etkilediği görülmüştür. Bu sebeple polis ve asker gibi güvenlik alanında görev yapmasına rağmen genel idare hizmetleri sınıfında çalışan infaz ve koruma memurlarına ihtiyaçları olan özlük hakları verilmeli, hem maddi hem de statü açısından toplumda hak ettikleri pozisyona ulaşmaları sağlanmalıdır.

İnfaz ve koruma memurlarının çalıştıkları cezaevi yapısının memurların iş doyumu ve tükenmişlik düzeyine etki ettiği görülmüştür. Bu sebeple yetkililer, infaz ve koruma memurlarına ayn tip cezaevinde uzun süre görev yaptırmamalı, farklı tip cezaevlerinde değerlendirmelidir. 
Genç ve orta yaşlı infaz ve koruma memurları kişisel başarı hissi boyutunda 40 yaş üzeri infaz ve koruma memurlarına göre daha fazla tükenmişlik yaşamaktadırlar. Bu sebeple göreve yeni başlayan ve orta yaşlı infaz koruma memurları için kariyer planlamaları profesyonel biçimde ele alınmalıdır.

Son olarak bedensel çalışmayı yoğun biçimde gerektiren, kendileri ve aileleri için risk içeren infaz ve koruma memurluğu mesleğinin bireyin iş doyumu ve tükenmişlik düzeyini etkilediği kabul edilmelidir. Memurlar için psikolojik danışmanlık hizmetleri üzerinde ciddi şekilde durulmalı ve psikolojik süreçler takip altına alınmalıdır.

\section{KAYNAKÇA}

Akın, M. M. (2010). Uluslararası İnsan Hakları Mevzuatı Açısından Türkiye'deki Cezaevi Uygulamaları.Yüksek Lisans Tezi, Kırıkkale Üniversitesi Sosyal Bilimler Enstitüsü, Kırıkkale.

Akınc1, Z. (2002). Turizm Sektöründe İş gören İş Tatminini Etkileyen Faktörler: Beş Yıldızlı Konaklama İşletmelerinde Bir Uygulama. Akdeniz Üniversitesi İ.İ.B.F. Dergisi, 4 (2), 1-25.

Aktaş, Ö. (2009) Ceza İnfaz Kurumlarında Güvenlik ve Gözetim Servisinde Çalışan Personelde İş Doyumu: Bolu F Tipi Yüksek Güvenlikli Kapalı Ceza İnfaz Kurumu Örneği. Yüksek Lisans Tezi, Abant İzzet Baysal Üniversitesi Sosyal Bilimler Enstitüsü, Bolu.

Atlandı, D. (2010). Çağrı Merkezi Çalışanlarında Tükenmişlik ve İş Doyumu Düzeylerinin İncelenmesi. İstanbul: Yüksek Lisans Tezi, Marmara Üniversitesi Sosyal Bilimler Enstitüsü, İstanbul.

Chen, Y. (2007). Relationships Among Service Orientation, Job Satisfaction and Organizational CommitmentIn The İnternational Tourist Hotel İndustry. Journal Of American Academy Of Business, 11 (2), 71-82. 
Cordes, C. L. ve Dougherty, T. W. (1993). A Rewiev and An Integration Of Research On Job Burnout. Academy Of Management Rewove, 18 (4), 621-656.

Çekmecelioğlu, H. G. (2006). İş Tatmini ve Örgütsel Bağlllık Tutumlarının İşten Ayrılma Niyeti ve Verimlilik Üzerindeki Etkilerinin Değerlendirilmesi. İş, Güç, Endüstri İlişkileri ve İnsan Kaynakları Dergisi, 8 (2), 153-168.

Davis, K. (1998) İşletmelerde İnsan Davranışı. K. Tosun vd. (Çev.). İstanbul: İstanbul Üniversitesi İşletme Fakültesi Yayınları.

Ergin, C. (1992). Doktor ve Hemşirelerde Tükenmişlik ve Maslach Tükenmişlik Ölçeğinin Uyarlanması. VII. Ulusal Psikoloji Kongresi Bilimsel Çalışmaları, Ankara: Türk Psikologlar Derneği Yayınları, 143-154.

Kaçmaz, N. (2005). Tükenmişlik Sendromu. İstanbul Tıp Fakültesi Dergisi, $68(1), 29-32$.

Keser, A. (2006). Çalışma Yaşamında Motivasyon. Bursa: Alfa Akademi.

Kırılmaz, A.Y., Çelen, Ü. ve Sarp, N. (2003). İlköğretimde Çalışan Bir Öğretmen Grubunda Tükenmişlik Durumu Araştırılması. İlköğretimOnline Dergisi, 2 (1), 2-9.

Köroğlu, Ö. (2012). İçsel ve Dişsal Doyum Düzeyleri İle Genel İş Doyum Düzeyi Arasındaki İlişkinin Belirlenmesi: Turist Rehberleri Üzerinde Bir Araştırma. Doğuş Üniversitesi Dergisi, 13 (2), 275-289.

Locke, E. A. (1969). What Is Job Satisfaction. Organizational Behavior and Human Performance, 4 (4), 309- 336.

Maslach, C. ve Jackson S. E. (1981). The Measurement of Experienced Burnout. Journal Of Occupational Behavior, 2 (2), 99-113.

Nunnally, J. C. (1967). Psychometric Theory. New York: McGraw-Hill.

Sat, S. (2011). Örgütsel ve Bireysel Özellikler Açısından İş Doyumu İle Tükenmişlik Düzeyi Arasındaki İlişki: Alanya'da Banka Çalışanları Üzerinde Bir İnceleme, Yüksek Lisans Tezi, Çukurova Üniversitesi Sosyal Bilimler Enstitüsü, Adana. 
Sürgevil, O. (2006). Çalısma Hayatında Tükenmişlik Sendromu Tükenmişlikle Mücadele Teknikleri, Ankara: Nobel Yayın Dağıtım.

Taşgın, G. (2004). Gençlik ve Spor Genel Müdürlüğü Merkez ve Taşra Örgüt Yöneticilerinin Tükenmişlik Düzeylerinin İş Doyumu Düzeylerine Etkisi. Yayınlanmamış Doktora Tezi, Selçuk Üniversitesi Sosyal Bilimler Enstitüsü, Konya.

Tümkaya, S. (2000). Akademik Tükenmişlik Ölçeğinin Geliştirilmesi. Hacettepe Üniversitesi Ĕ̆itim Fakültesi Dergisi, 19, 128- 133.

Vroom, V. H. (1964). Work And Motivation, New York: Wiley.

Weiss, D.J. ve Dawis, R.V. ve England, G.W. ve Lofquist, L.H. (1967). Manual For The Minnesota Satisfaction Questionnaire, Minnesota: Studies In Vocational Rehabilitation.

Yılmaz, İ. (2006). Verilerin Çözümlenmesi-İlişki-Korelasyon. Yüksek Lisans Tezi, Ankara Üniversitesi Sosyal Bilimler Enstitüsü, Ankara.

\section{Kaynakça Bilgisi / Citation Information}

Kayra, M. ve Dikmen, A. A.(2017). Cezaevlerinde görev yapan infaz ve koruma memurlarının iş doyumu ve tükenmişlik düzeyleri arasındaki ilişskinin incelenmesi. OPUS - Uluslararası Toplum Araștırmaları Dergisi, 7(13), 524-551. 